\title{
SUFI QUR'ĀNIC EXEGESIS AND THEOMORPHIC ANTHROPOLOGY
}

\author{
Stephen Cúrto \\ Union County College New Jersey, United States \\ E-mail: scurto@scarletmail.rutgers.edu
}

\begin{abstract}
Of all the various ideological controversies in the history of Islamic thought, a highly contentious area is that which surrounds the ontological nature of the Divine attributes or Sifät Allah. Questions surrounding God's attributes and what delineations to be made between this nature and Being, known as Dhät Allah, preoccupied some of the greatest classical participants in the ilm al-kalām systematic theological disputation tradition. Therefore, this study engages Qur'ānic paradigms of theomorphic anthropology and re-interrogations by Sufi thinkers. A rich debate occurred within the Islamic Scholarship on the nature of the Divine attributes and their interrelationship with Banī Adam. Many of the mystical Sufi scholars, such as Ibn 'Arabī, Mūlla Sadra, Nāṣir Khusraw, and Abū Hāmid al-Ghazālī all articulated onto-theological concepts in their writing. These works became known as Waḅdat al-Wujüd, Tajalli Allah, Tajalli al-Nafs' Nafs-e 'Aql, and Nafs-e Kül. Consequently, this paper argues that the idea of Divine immanence articulated in concepts like 'Tajalli al-Nafs' is not a later retrojection onto Qur'ānic material. Rather, it is the Qur'ānic material that was exegeted with a meaningful and consistent hermeneutic, which resulted in their theosophical understandings.
\end{abstract}

Keywords: Allah, Qur'ānic Paradigms, Theosis, Tajalli, Divinization, Theomorphism.

\section{Introduction}

Of all the various Ideological controversies in the history of Islamic thought, one of the most highly contentious areas are those surrounding the ontological nature of the divine attributes (Sifät Allah). Such questions, surrounding the attributes of God, and what delineation, if any, is to be made between the nature of God in his divine attributes (Sifät Allah), and in his Being (Dhät Allah) 
preoccupied some of the greatest disputants in the ilm al-kalam systematic theological disputation tradition. ${ }^{1}$

The concept of theosis and theomorphism have received much attention from scholars engaged in the study of Patristic theology. ${ }^{2}$ However, and most regrettably, the idea of humanity's divine nature, whether by the process, or ontology, as a specific field of inquiry within the Islamic tradition, has not been as energetically pursued by the academy. Even more problematic is the tendency for some voices within the academy to see mystical ideas of Sufi thinkers as anachronistic. Many have seen the articulations of mystical exegetes as derived from non-Qur'anic importations into the exegetical framework of this later mufassir. Interestingly, one of the few examples of scholarly attention on this subject has seen parallels to theosis's patristic modality, and we argue rightly so. ${ }^{3}$

There was a robust discussion on whether the deity attributes were a separate ontological category from his Being in classical Islamic theological discourse. Both the words dhat and wujüd have been widely used as technical terms to denote God's Being, as a distinct ontological category from the Essence of God, when such delineations were asserted. Ibn 'Arabī (1165 C.E./560 A.H.-1240 C.E. 637), for example, is well known for his use of the ideological concept of Wabdat al-Wujud, to describe God's ultimate reality as a manifest, non-delimited unicity. ${ }^{4}$

1 See Mulla Sadrā, The Elixir of the Gnostics, trans. William Chittick (Provo, Utah: Brigham Young University Press/the Islamic Translation Serious, 2003), 8. For some further examples and discussions on this see, Al-Bāyhaqī, Allah's Names and Attributes, trans. Gibril Haddad (Fenton, MI: As-Sunnah Foundation of America 1999); Ibn Taymiyah, al-'Aqidah al-Wasatiyah (Riyadh, SA: Darussalam, 2009); Allāmah Jamāl al-Dīn al-Hillī, Sharh al-Bāb al-Hādì 'Ashar (Anwar al-Hoda Publications, Qom: IR: 2012); William C. Chittick, The Self-Disclosure of God (New York, NY: SUNY Press, 1998); Abū al-Hasan 'Alī b. 'Ismā'îl al-'Ashā'rī, Maqālāt alIslämiyyin (Beirut, LB: al-Maktabah al-Așrìyah, 1990).

2 The work cited below is an excellent introduction to just how normative theosis was in historical patristic theology.

3 Axel Takács, "Becoming the Word: Theosis in the Eucharist and the Qur'ân" Journal of Ecumenical Studies, Vol. 46, No. 1 (2011).

${ }^{4}$ While many would posit, he actually never used the term itself; the matter is far from settled. While largely outside the scope of this paper, Part of this hinges on what the 'canon' of Ibn al-'Arabî's writings is accepted to consist of; there is inarguably manuscript attestation to various treatises' utilizing the term Wabdat al$W u j \bar{u} d$ in works attributed by the scribe of these said works to Ibn 'Arabi. However, they are generally regarded to be the works of later authors; pseudonymous or 
Specifically, this idea, that all things are pure of other than God, is inarguably and unavoidably replete in his work. While amenable to a number of interpretive exegetical frameworks from which to view this discourse, including what may be clumsily termed pantheistic (rather, if anything it is panentheistic) his metaphysical theosophy is one if immanence. The names and attributes (al-asmä' wa al-sifät) or dhät (being, in the sense of essential essence verses attributes) or wujüd (being, used by the aforementioned Ibn 'Arabī in the sense of ultimate ontological nature of one from the category of existent things, in this case God) regularly made appearances in the classical 'aqidah and 'ilm al-kalam literature. The noted prolific Shī'i philosopher and Qur'ānic mystical exegete Mulla Sadrā for example presents a highly nuanced presentation on the ontological interrelationship of the dhät and al-asmä' wa al-sifät.

The present study argues that the Qur'ānic paradigm of anthropology is one that presents, in no uncertain terms, humanity as being granted a 'divine' status.

\section{Qur'ānic Theosis: Adamic Viceregency and Paradigms of Divinization}

Theosis, or the process of humanity ascending to divine status, either by gaining access to what one is intrinsically by nature; or by manifesting by knowledge, faith, and deeds, ontologically divine status is a scriptural anthropological reality described at multiple points in the Qur'ānic narrative. Perhaps the ayät with the highest centrality to this idea is the Qur'ānic depiction of the ensoulment of bani Adam, which is met with in multiple instances, such as is the described in the $15^{\text {th }}$ ayah of Sūrah al- Hijr:

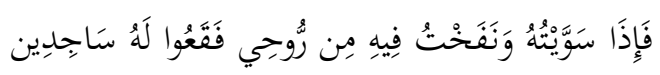

In another place, The Holy Qur'ān informs us in the $72^{\text {nd }}$ verse of Surah $S \bar{a} d$ the exact same nature of the divinization of bani Adam by means of ensoulment (Q.38:72). This event, also described at length at Q. 2:34 Q. 7:11and Q. 15:30. In all this, there is the command for angelic prostration. Further, it is the special divine act of blowing into what has been formed by God a Soul from Himself that

misattributed. Likewise, we find the concept, if not the direct technical vocabulary, soaking his works. For a discussion of this, see Abdul Haq Ansari, Ibn 'Arabi: the Doctrine of Wabdat al Wujüd', Islamic Studies, Vol. 38, No. 2 (1999), 149-192. 
now consubstantially indwells this special exalted creation that necessitates the divine bowing of the divine council of angelic hosts. In the contexts of these verses, it is diabolic resistance that among the entirety of the divine assembly is the only resistance to this command that we meet within the text. It is exactly this rebellion to acquiesce to The God's command to prostrate to Mankind as the divine being that is the genesis of the shaytan project of rebellion against God and Man.

This theme is likewise asserted at Q. 17:16 Q. 18:50, and the heavy repetition of this narrative is indicative of its theological importance to the Qur'ānic anthropology and merits serious attention. Such consideration is especially warranted, on account of another Qur'ānic injunction, that nothing makes Sajida, except to Allah (Q. 41:37). The Qur'ān presents an anthropology wherein the sun and moon, and even the angelic hosts of the 'divine council' have no felicity whose merits even approach those given the Adamic "Universal Soul".

We are presented with this essential component of both Qur'anic onto-theology and anthropology, fairly early within the ordering of the Qur'ānic narrative as a whole within Q.2:29-34. The establishment of this scriptural precedent for man's idea as khalifa directly informs the irfani paradigm of the tajalli al-Nafs as tajalli Allah. Specifically, this can be read as a form of name theophany, and it is rather striking-sg that it is within the context of God setting his viceregent upon the earth where the Adam pedagogical didactic with the angelic hosts in regards to 'the names' is mentioned.

Turning again directly towards the text, we are called to remember when God informed the angels that he will create a viceregent in the earth. When the angelic objection is raised that perhaps this creature might cause fasäd in the earth. However, the answer to this objection is that God knows something that the angelic hosts do not collectively yet known. In Q. 2:31, we learn Adam teaches the angels the names all of them, and then displays them or manifests them to the angles. This point in the text and the semantic domain of the words ism and 'aradahum 'ala al-maläikah and what is intended by their usage is of great importance to this central thesis. Indeed, how we parse this piece of text has direct implications for a host of claims appertaining to claims about both theological and anthropological Qur'ānic paradigms. 
For instance, one could rightly ask, who is being taught? Is it Adam as a student, for example, a prior to the angels? Structurally, the most 'natural' reading would be 'Allah [teacher] instructs Adam [student] then after he taught Adam, then Adam [teacher] instructs what he has learned from Allah to the angels [students]. However, when we read the text in its larger narrative context, both at this point and with all the intra-textual relationships to parallel Qur'ānic narrations, there are at multiple, equally coherent ways of reading the text. In short, the standard way of reading the text, (with some slight digressions at different theologically relevant points depending on the exegete) is as follows:

We can see the narrative as being God teaching to Adam all the names. Then he displays them to the angels. After this display, he (God) requires the angels to inform Him about the names if they are from the truthful and righteous. The angels, in light of the default angelic position towards tastim and sensing the rhetorical nature of this inquiry, and because there was perhaps something rather revelatory in the display, of course, respond with deference to that request and courteously abstain.

God then instructs Adam to inform the angels by means of their names, and when he does so, God, on the basis of the Adamic felicity just demonstrated by the informational imparting upon them by means of the names, rhetorically asks the assembly of the divine council "Did I not say I know what you all know not?" Then God asks the angels to make sujüd directly to Adam, or, as is often repeated in commentarial works, to God by means of prostration to Adam. All do so, save the one diabolic among them.

In general, this is the standard way of reading the text both among Muslim and non-confessional secular academics. This is not, however, the reading that I propose. There as some grammatical as well as exegetical issues inherent with that line of argumentation that is a highlight. Thereafter, different exegetical reading of the text is presented, an understanding of the text which I argue enjoys the most thematic coherence and explanatory power.

\section{Encountering Man as Divine Being: Modalities of Adamic Name Theophany}

At the outset, we must insist that the word 'names' (ism) is actually not the primary semantic domain intended by ism at this point 
in the Qur'annic text. Rather, it is the pan-Semitic connotation of the idea of the presence of a thing, especially a deity that is meant here. On this point, Julien Véronèse observes, “...Using one or more of God's names embody the Verb par excellence, the creative and efficient language fragments...revealed to a certain people in order to cement a special place between them and divinity..."

That should be kept in mind as forming a central exegetical presupposition before engaging with the narrative.

Returning to our direct analyses, the verses start with the assertion that God will be placing a kbalifäh "a successor" on the earth. Now, the semantic domain of khalifäh is from amongst the most important theological and narrative points in establishing a meaningful exegesis of the narrative. What is meant by a khalifäh here is not peoples or tribes having children who, as the next generation, will be "succeeding" their parents, and therefore creating a people who will be successors to one another on the earth. This is admittedly one of the understandings found in the commentarial tradition, classical and modern, but it lacks on many substantive grounds. Those deficiencies are likewise noted by other voices in the classical and modern commentarial tradition. We will suffice to say that first, the word here is a singular noun, and the text does not say I will place Khülafäh on the earth. This would be the case if parents and their children in 'endless' successive generations was meant.

Clearly, the singular use of the word (khalifäh) here is an excellent example of when a grammatically singular noun is standing for a plural concept. If someone were to say, for example, "A ruler shall not depart from Judah" or "Qom will never be bereft of a scholar or a marja' taqlid" or "Japan shall never be empty of the cherry blossom," a singular ruler, or an individual scholar, or a specific cherry blossom tree is obviously not intended.

${ }^{5}$ Julien Véronèse, "God's Names and Their Uses in the Books of Magic Attributed to King Solomon” Magic, Ritual, and Witchcraft, Vol. 5, No. 1 (Summer 2010), 30.

For a discussion of the ubiquity of deity names as divine presences. See also Alexander Fodor, "A Group of Iraqi Arm Amulets: Popular Islam in Mesopotamia”, Quaderni di Studi Arabi, Vol. 5/6 (1988), 259-277. Spencer Allen, The Splintered Divine: A study of Ishtar, Baal, and Yabweh Divine Names and Divine Multiplicity in the Ancient Near East (Boston: de Gruyter, 2015); Benjamin D. Sommer, The Bodies of God and the World of Ancient Israel (New York: Cambridge University Press, 2009); Ali Fakri Dögen, “An Outline of Qunawi's Reflections of Divine Names in The of Oneness of the Being/Wabdat al-Wujud", Mütefekekir, Vol. 1, No. 1 (Spring 2014). 
Likewise, if the idea of generations procreating successive generations is not intended, what is especially, and we insist emphatically not a possible contender is the stymying suggestion that what is meant by khalifäh is a person or persons who, by military campaigning, will shed blood. To posit that nation rising against one another to then be "successors" of each other, is essential to offer as an interpretive hermeneutic the recapitulation of the initial angelic objection. This objection is one that is soundly refuted by the deity later on in the narrative.

Now, irrespective of the potential for bani Adam to be those engaged in bloodshed, that cannot coherently be what is intended by khalifäh. This stands true on multiple grounds, most strongly, as previously mentioned, the internal logical grounds. The angelic objections to the introduction of another order of creation to fit the status of khalifäh are inclusive of the idea that there is something inherently special or noble about being a khalifah. The angelic prognostication that this Adam may be unworthy of this title is in part because of their fear he will have this propensity, whereas then they are in constant submission to deity.

Hence there is something of inherent worth in the status of being a khalifäh already hinted at in the status of being a khalifäh that being prone to unwarranted violence would generally preclude one from being worthy to obtain. Further, why would Allah have to say that he knows something the angelic hosts are ignorant of if the definition of khalifäh is by nature what they put forth an inquiry about. In other words, if that was the case, could not have the answer from God to the angels have simply been yes, your correct, full stop?

The deficiency in adopting the above vantage point is highlighted in the commentary of al-Maturīiñ; the imām relates a tradition that when it is said, "will you create a person on the earth who will cause corruption and wrongdoing" the speaker voicing this 'angelic' objection is actually Iblis. ${ }^{6}$

Al-Maturìdi presents some of the most explicit assertions of Adam's nature as he viceregent representative of God on the earth: saying he was to establish God's Judgement over creation, to judge between them, and to establish his religion

\footnotetext{
${ }^{6}$ Abū Manșūr al-Māturīdī, Tämìlāt Abl al-Sunnah, Vol. 1 (Beirut: Dār al-Kutub al'Ilmīyah, 2005), 413.
} 
Khalifäh is then most correctly then understood in the meaning of being a 'viceregent' or a divine agent on earth "representing" in duty, role, and characteristics, the absolutely transcendent God. Such a reality can be seen within the narrative of the $79^{\text {th }}$ verse of Sürah $\bar{A} l$ 'Imrān, which contains direct divine injunctions that call toward theosis, commanding the people to 'Be Lords' in a fi'il amar of grammatical construction (künū rabbänìyin).

Further, by 'aradahum what is meant is literally manifesting, not simply showing, and that the harf jahr "alä" at this point in the text literally means 'upon'. In other words, what we have is a theophanic condescension. The divine answer to the angelic objection is a tajalli of the totality of the divine names within Adam. This manifestation of a name theophany exemplified to the angels furnishes a proof that impresses fully upon the angels the full meaning of God's saying, "I know what you do not know" vis a vis the Adamic creation event. When turning to the classical commentarial tradition, we find that this is a very well-represented interpretive option within the discourse.

This was what was noted by Ibn 'Arabī, who observed in the Fususs al-Hikam "All of the Names, which are divine forms, are manifested in this makeup of man and the function of encompassment and synthesis is achieved through his existence. God's arguments against the angels stand on this".

In classical commentarial works, many opinions are related. Ibn Jarìr al-Ṭabarī, records that "the names, all of them", for example, meant that God taught Adam the names of all the most magisterial pillars of creation, the sky, the land, the mountain the earth, the sea, etc. $^{8}$ and it was Adam who named these things by these names. Another of the opinions transmitted from 'Umār (which likewise corresponds to many similar rabbinical midrashim) is that the 'names' in question are the names of the angels" (an intriguing facet of this idea will be highlighted later on). Al-Ṭustarī records it was from an admixture of clay and the logos of the numr of Muhammadan reality

\footnotetext{
${ }^{7}$ Ibn 'Arabī, The Ringstones of Wisdom (Fusüs al-Hikam), trans. Caner Dagli (Chicago: Kazi Publications, 2010), 6-7.

8 Ibn Jarìr al-Ṭabarī, Tafsìr al-Ṭabari, Vol. 1 (Beirut: Dār al-Kutub al-'Ilmīyah, 2014), 252. Hadith 636.

${ }^{9}$ Ibid., 253.
} 
that formed Adam, endowing him with divine attributes with which to fight the lower self. ${ }^{10}$

Likewise, the classical commentarial tradition is perhaps the strongest attestation to the understanding of the khalifäh as being a divine status. Turning to the Kitab al-Tafsir in Șahīh al-Bukbär, we find that the Prophet directly states the meaning of Khalifäh is Khalifäh Allah.

"From the Prophet (S) who said, "the believers will be gathered of the Day of Resurrection...to Adam it will be said you are the father of humanity, the Successor of God (Khalifäh Allah) formed by means of his hand, and to you, the angels were commanded to make sujū '. ${ }^{11}$

Further, we likewise therein have the most compelling attestation to the idea that the names that were imparted to Adam were the Divine Names proper. This also intersects directly with the previously mentioned opinion that the names were angelic names earlier mentioned. We find Kitab al-Tafsir in Sahīh al-Bukhäri, an extensive number of traditions reported that the names of angels such as Mika'îl or Jibra'il contain the Divine Name and the explicit assertion that the names are from the Hebrew language, with the name of God that forms part of the angelic naming conventions. In hadith no. 448, for example, we find the Prophetic statement.

$$
\text { كل اسم فه إيل فهو اسم الله... إيل الله بِالعبرانية } 12
$$

This is not simply an exegetical point. It is likewise a lexical one. Although as many lexical authorities consider ${ }^{13}$ Adam as maf ${ }^{4} \bar{u}$ bih of 'he taught' making it and he (Allah as the hidden damir) Adam the names, all of them; one likewise read Q. 2:31 as "And Adam taught them the names, all of them". The text is amenable to a variegated number of interpretive readings. Here we do not have to believe that God taught Adam the names here, although that is inherently implied, for the creator is the one who illumined all men's minds; rather although when read with the taskbil in 'allama Ádam we can read "and

${ }^{10}$ Sahl b. Abd Allah al-Tustarī, Tafsìr al-Tustari: Great Commentaries on the Holy Qur'an, trans. Annabel Keeler (Louisville: 2011), 16.

${ }^{11}$ Ibn Hajar al-'Asqalānī, Fatḥ al-Bāri: Sharḥ Saḩ̄ḥ al-Bukhārì, Vol. 9 (Beirut, LB: Dār al-Kutub al-'Ilmiyah, 2009), 136.

12 "Every name that contains in it the 'el' suffix contains within in the name of God... El/Eloah is the name of God in the Hebrew Language." Ibid., 141.

13 Muhy al-Dīn Darwīsh, I'rāb al-Qur'ān al-Karim, Vol. 1 (Damascus: Dār alYamāmah, 2014), 86-87. 
He (God) taught...". However, the consonantal orthography itself does not necessitate "taught Adam" For example, similarly can say "Adam Taught" just as we can say that "God created" (khalaqa Allab)." The "Uthmanic rasm could easily accommodate either reading. ${ }^{14}$

What God knew that the angels were unaware, the theomorphic qualities inherent in Adam's ensoulment is not only asserted but demonstrated by Adam's display of the divine names and attributes. On this demonstration of inherent theomorphic display to the angelic hosts by the Adamic reality as a name theophany, Mullā Sadra observers "With respect to the point of view that man contains all that is in the microcosm (al-'álam al-Kabir) it is because his perfect configuration (nash'atubu al-Kämilah) is the locus of all the divine names and attributes..."

\section{The Qur'ānic Paradigm of Theosis as Divinization via Self- actualization}

Further, what I contend is this a-temporal theomorphic ontotheology cum anthropology is described in Q. 30:30. Therein, the reader is presented with a description of the fitrah of bani Adam that is a direct divinization presentation. This is concomitant with the Qur'ānic and Irfani paradigm of theosis, which has been highlighted, theomorphism is humanity's inherent nature; it is who he is and what he does.

Within Q. 30:30 the reader is presented with an exhortation and a reminder.

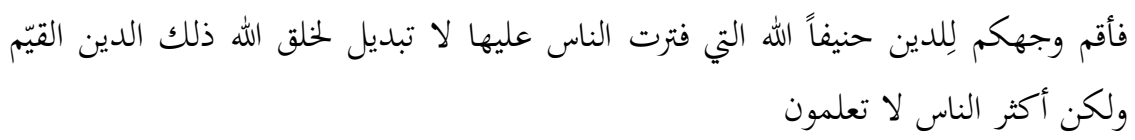

The Qur'ān here exhorts its audience to turn to be established firmly with their whole essence with the way of those who have

14 Although somewhat outside the scope of this paper; many exegetes have noted that the rasm may lend itself to very plausible and reasonable alternative readings. The great Qur'ānic mufassir and theologian 'Allama al-Tabātabā'̄ proffers an extensive discussion in his famous work al-Mizan on the merits of understanding rabb al-älamin as rabb al-älimin with specific connotations of Allah as the nourisher of the sentient beings/minds, not rabb al-älamin. He grounded this argumentation on the merits of the ubiquity of the plural awalim used for worlds. Readings being proposed that are amenable to the Qur'annic rasm but not part of the more common taskbil transmitted in more common riwayat such as Hafs is by no means idiosyncratic within the history of Qur'ānic exegesis.

15 Mohammed Rustom, The Triumph of Divine Mercy: Philosophy and Scripture in Mulla Sadra (Albany: SUNY Press, 2012), 71. 
turned towards God. The concept of mankind as inherently divine is perhaps nowhere as strongly asserted. Although often this can be glossed over due to the differing ways that we can understand this text, there is language herein strongly suggestive of Qur'ānic theomorphic anthropo-ontology.

Suppose we encounter the text from this perspective. In that case, faaqim has, I contend a possesses a rhetorical simultaneity of meaning, both firmly established and raised up upon the banafi din, (possessing it in fact by nature) and likewise of qãwm, a nation whose essence (wajd); the full weight of the bifurcated resonances of meaning here met within the phrase li khalq Allah dhälika al-din al-qayyim.

It was serving as indexicality of the exhortation to the cultivation of divine status. Establishing oneself upon the hanafi din is to cognize the nature of who one is by nature of the inherent ontological status simply by being bani Adam. This is the religion of people because it is the very nature by which the fitrah of humanity was formed and molded upon, and they can never be alteration in the creation of Allah. Here I take this as a statement of fact, not simply a warning against violating normative God-ordained socio-religious practices, but a direct statement of anthropology Mankind was formed upon the hanafi fitrah and there is no altering Allab's creation. Mankind is literally formed and molded upon this fitrah. Here the lexical-semantic domain of hanif, fitrah, din, wajd, and the grammatical possibilities of this verse are tremendously exegetically significant.

The Qur'ān says, "Firmly establish (or raise and exaltation) your entire essence with the hanafi din". While hanifah possesses several meanings in this context, its semantic domain of turning towards is not lost. Certainly, when taken in this regard, we meet with a specific portrait is painted regarding the status of being hanifah as comprising a universal religion, or rather, a divine culture imparted to humanity via a-temporal ensoulment

This is an exhortation to become firmly established upon the fitrāh Allah and this construct, with the intra-Qur'ānic exegesis that the fitrah of God "...that is the fitrah of mankind upon which he was formed, there is no altering Gods creation." Man's nature (his fitrah) is God's Nature, his fitrah, bani Adam being formed upon that mold collectively, and there is no alteration in what God has formed; man is by nature a divine being. Further, although this is the religion of Qiyamah of the 
station of mankind before God, the majority of humanity is ignorant of this divine status before Allah as his theophany.

This kind of theomorphism is at once inherently preservative of unitarian monotheism, and yet arguably an even stronger assertion of the image bearer pan-Semitic religious theologeme whereby in Biblical and extra-biblical literature, as well as a vast plurality of 'aḥadith literature, the themes of Adam as 'image-bearer' or 'image and likeness' of God is met with. Here hoverer the Qur'ānic theme of mankind's theomorphic status is his very nature, his fitrab itself, which is the tajalli al-Nafs as a modality of tajalli Allah.

\section{The 'Arsh Allah and the Qur'ānic Semiotics of Theomorphic Anthropology}

Verses 19-22 of Sūrah al-Anbiyā' present a significant series of cosmological assertions highly relevant to contextualizing both the theological conception of the throne of God, and the idea of the immanence of the deity in a Qur'ānic framework. Verse 19 asserts that "And with him belongs whoever is in the heavens and from the earth. And those with him ( indabu) are not too arrogant to be kept from 'ibada nor are they those who desist." We are informed further on the subject in verse 20 , that they glorify him day and night, and never cease in doing so (lä yaftarün). This establishes several important exegetical elements. First, there are three important categories of being established, the heavens, the earth, and those with, or in possession of, or special relationship to, proximity with God. The rhetorical significance of the phrase indahu in the context of the totality of the narrative in which it is situated is great, and it should not be glossed over. Although the phrase inda, as Lane notes "signifies at, near, nigh, by, near," 16 the words primary signification was that of "denoting presence... i.e., perceptible presence, and also ideal presence ... the place of presence... and utmost nearness". ${ }^{17}$

Of these beings, the question is asked, "Or have they taken gods from the earth who give life? If there were in them gods besides Allah, they would have both been in disorder. So glory be to Allah, the Lord of the Throne, being above what they describe? 18

${ }^{16}$ Edward William Lane (ed.), An Arabic-English Lexicon: Derived from the Best and the Most Copious Eastern Sources, Vol. 5 (n.d.: Nabu Press, 2009), 2171.

17 Ibid.

${ }^{18}$ Q. 21:21-22. 
The throne of God ('Arsh) here functions as theologeme in a highly significant way in the passage's rhetorical and theological context. However, since this significance lies in what the verse is affirming the ontological nature of what nature 'Arsh is, it is part of the broader cosmological and theological messaging of the verse, not simply an oath that God is the 'Lord of the Throne'. The verse's context makes the 'Arsh language part of a complex intra-textual discourse on the concept of bulül or the divine presence's indwelling. The Qur'ānic narrative in verse is here addressing all categories of creation (verse 19, wa labu man fi al-samäwät wa al-arḍ) explicitly and directing attention to those directly in communion with the Divine presence who especially are not too haughty to serve and worship. ${ }^{19}$ The polytheists and unbelievers are addressed, and the rhetorical question is posed in verse 21, "Have they taken gods from the earth other than Allah?" Such a course of action would be not only the height of ignorance but also an impossibility, we are told, the text continues, because there are simply no ontologically real deities in them $\left(f_{i h i m a}\right)^{20}$ any of them (the heavens, the earth, or the ones enveloped in the Divine presence) other than The God. And rather, the one God is indwelling them all, heavens, earth, and the created beings; some in a special way (indabu).

These are the ones who slacken not (la yaftarün) from their 'íbada nor do they tire doing so, day or night, for the reason that resultant from their station (indahu) they are a locus of divine manifestation ('ársh) and the people, or angels, or jinn, et al who have taken "gods" from the Earth in contraposition to the worship of the God, and the proper recognition of the indwelling of the Divine presence, are astray and resultantly have wrongly erred in subsequently deriving from this folly the worshiping of false deities. As the accomplished Abmadi translator Muhammad Ali observes on the question of the throne to which we now direct our attention, "Note that here Allāh is spoken of as Rabb al- 'Arsh, the nourisher unto perfection ("Lord") of the 'Arsh so that the 'Arsh, or the Throne

\footnotetext{
19 The connection between ibädah and khalifah is highly significant.

20 While fibima itself is morphologically dual, the context of the rhetorical questioning in verse is inclusive of the 'Heavens' the 'Earth' and those from the creator who would take gods from the heavens the earth, or themselves other than Allah.
} 
itself is sustained by God, and it is not God who is sustained by the 'Arsh". ${ }^{21}$

The verse then is a rhetorical insistence on the futility of the false category of worship amongst those who have "taken gods other than Allah" from the earth, falsely thinking they can give life, with the catena of the narrative declaring that there are no gods other than the God, who is to be found in the heavens, the earth, and in themselves. There cannot have been with them any "gods" other than the God, in whom the divine presence is both omnipresent and indwelling. The only one ontologically valid worship category, none can be thought of as encompassing mankind or the earth in such a way other than The One true God. These categories of being, the heavens, the earth, and their inhabitants are the throne in question. Gods imminence is presented in the text as omnipresent, and the narrative insists his throne is encompassing the heavens, the earth, and the friends of God. This is why the phrasing chosen by the Abmadi translator Muhammad Ali was to opt for functional, or dynamic equivalence, ${ }^{22}$ and render verse 21 literally as "in them" (fibima) rather than "in the heavens and the earth" or "in them both" as other noted translators have done. Grammatically and contextually, this is the correct opinion, as, even though the use of the plural is used in classical Arabic for more than two categories of being, based on the rhetorical context, delimiting the reference to solely the heavens and the earth does not accurately reflect the grammatical and contextual considerations, let alone do justice to the nuanced dimensions of the theological messaging present in the narrative structure of the text. As the mystic and scholar al-Ghazali writes in his seminal commentary on these verses Miskhät al-Anwär ('the Niche of the Lights').

Perhaps you desire to know the manner in which God's light is ascribed to the heavens and the earth-or, rather, the manner in which God is the light of the heavens and the earth in His own essence... know that God is light, that there is no light other than He, and that $\mathrm{He}$ is the totality of lights and the Universal Light...an expression for that through which things are unveiled; in a higher

21 Maulana Muhammad Alī, The Holy Qur'an: Text, Translation, and Commentary (Dublin, OH: Ahmadiyya Anjuman Isha'at Islam, Lahore, inc. 2002), 651

${ }^{22}$ Rather than strictly formal-equivalence. 
sense it is through that which, for which, and by which things are unveiled. $^{23}$

These verses (Q. 21:19-22) in the light of the linguistic framework and the context of the Qur'ānic rhetorical structure in which they are situated greatly inform our conception of the how the Qur'ān outlines the 'al-asmä' wa al-sifät of Allah as a harmonious simultaneity of the two polarities of tanzih and tashbih. This framework is one wherein God's ultimate transcendent reality (tan₹ih) necessitates, rather than precludes, his immanent presence and selfdisclosure. This self-revelation then becomes the form or likeness (tashbih) by which He becomes known to the knower.

The Qur'annic narrative presents the 'Arsh, or the 'throne' of God as central to God's idea in his sovereignty and dominion. The Qur'ānic narrative, when closely read, reveals it is likewise related to the tajalli Allah, God's theophanic self-disclosure of God through the agency of mankind. Mankind in general, (as the unique creation of God), and those special men and women specifically, are ontologically related to the throne itself, and function as a 'throne theophany. ${ }^{24}$

The $79^{\text {th }}$ verse of Sūrah Āl-'Imrān (a verse which directly intersects the concept of mankind as throne theophany and the full implications of Tbada) reads: "It is not for the creation, who verily are granted the Book, and the Wisdom, and the Prophet-hood, to then say to the people, be in a state of 'ibàdà to me, from other than Allah, but instead, kinnu rabbaniyyin by means of that which you teach, and by means of that which you study".

The command that is given, kimn rabbaniyyin, is both theologically and exegetically significant, especially in the context of the previous mention of 'ibädä, in structural parallelism, ${ }^{25}$ as is discussed below. The command given here is plural, and there is no reason to suspect that it is delimited to any one individual or referencing any specific prophet. Rather, it is a general command, first to those from amongst the creation who are charged with the prophetic office (al-

\footnotetext{
23 Abū Hāmid al-Ghazālī, The Niche of Lights, A Parallel English-Arabic Text (Provo, Utah: Brigham Young University Press, 1998), 19.

24 This term in both Biblical and Qur'ānic studies relates to how both the 'ärsh and the kürsi, or the merkavah function as part of a theophany.

${ }^{25}$ For a discussion of the different Qur'annic usages of various literary structures, see Mustansir Mir, "Some Figures of Speech in the Qur'ān", Religion and Literature, Vol. 40, No. 3 (2008), 31-48.
} 
nubuwwah) and simultaneously to the people (al-nās) to be Lords or to be Lordly.

The specific verbal command construction künu rabbaniyyin is rather rare as a construction in the Qur'ān, however, both the qira'ät of Imām Hafs and Imām Warsh ${ }^{26}$ give the reading as künu rabbaniyyin, ${ }^{27}$ and there is no significant textual variant here. The word rabbann in Qur'ānic usage is comparable to the word rabb and can connote a Lord, a Scholar, and a Rabbi. It is bighly unlikely that the Qur'annic narrative is encouraging its audience to become rabbinical clergy, and the use of the plural form of the word rabbann here is best understood as a command to be functionally Lords.

While this is not at all in opposition to the warning against those given the kitäb ('the book') and the bikmah ('the wisdom, the ruling, or the understanding'), from telling people to worship themselves ( $i b \bar{a} d \vec{a})$ in contraposition to the One God. Indeed, this exertion is explicitly directed to be inclusive of the people (al-nās), not just those in the prophetic office (al-nubumwab). Rather, becoming 'Lords' on the basis of having taught and studied the Kitäb is the very fulfillment of 'ibadab in the Qur'ānic narrative. It is part of the tripartite mandate given to Bani Adàm to be worshippers ( in the $56^{\text {th }}$ Sürah al-Dhäriyät, agentival representatives (Khalifäh) in the $30^{\text {th }}$ verse of Sürah al-Baqarah, and lords upon the earth (künu rabbaniyyin). This Qur'ānic injunction is also enjoining on mankind. The command to fulfill far more than can be delimited to the cultivation of scholastic acumen. Rather, it is inclusive of mankind being nourishers, and sustainers as Lane and Ibn Manzūr both recorded this is inclusive within the semantic domain of rabbann.

\footnotetext{
${ }^{26}$ Two of the most well-received and widely distributed recitations are those of the two Imāms of Qur'ānic recitation (Qira'āh) Abū 'Amr b. Sulaymān, al-Küfì (Hafs) Lived 90-180 Hijrì, and Abū Sā'īd al-Qutbī (Warsh), 110-197 Hijrì. Warsh is particularly well-represented in the Maghreb, and Hafs is the most widely distributed Qur'ānic recitation everywhere from Iran to Saudi Arabia. The standardization of the Hafs Qir'àt by the 1924 Egyptian Edition (Cairo) is still the 'textus receptus' as it were for the printing of the Qur'ānic text. It currently enjoys wide distribution by virtue of the prolific printing project of the King Saud Printing center in Saudi, and many other printings of both Hafs and Warsh follow its pagination and verse divisions.

27 Al-Qur'ān al-Karim bi Riwāyat Warsh (Damascus: Dār al-Ma'rifah Publications, 2008), 60. Al-Qur'ān al-Karim King Fabd Glorious Qur'ān Printing Complex, (Medina: 1999), 60 .
} 
The Qur'ānic description of the 'arsh form part of the narrative assertions of cosmology wherein there is synonymic parallelism between the 'throne of God' and the human being, especially the human beings who fulfill the $253^{\text {rd }}$ verse of Surah al-Baqarah (Q. 2:253) regarding those of whom the Qur'ān describes as "those messengers to whom we gave bounty, some we gave abundance upon abundance. From them are those to whom Allāh spoke, those raised by Allah in exalted degrees of rank. And given unto Jesus, the son of Mary was the manifest clarity, we strengthened him by means of the Holy Spirit." ${ }^{28}$ These exalted messengers function as the locus of divine manifestation of the arsh in a temporal sense in the world, as ontological and agentival reflections of a temporal arsh by virtue of being extensions of, and indwelt by, the divine presence.

The Qur'annic narrative supports this exegetical conclusion, and itself connects the theologeme of the throne of God and the human being through the medium of water. The Qur'ān describes the 'arsh Allah as upon the waters in Q. 11:7 "And he was the creator of the heavens and the earth, and His throne ('arsh) was upon the waters $\left(M a^{\prime}\right)$ " The Qur'ānic discourse further employs that same diction in the context of mankind, asserting that "...And the Heavens and the earth were joined... and we formed from water all things" in Q. 21:30. We have then the parallelism of the usage of kull shay' (all things) in the context of the throne ('arsh) in Q. 11:7 in the context of being given to the Queen of Sabä', the 'arsh of God being upon the waters( Q. 11:7,) and kull shay' being made from water in Q. 21:30. The Qur'ānic narrative is employing this intertextual parallelism of the Narm of 'arsh, and $M \bar{a}$ ', illustrative of the fact that the human being, (especially prophets or friends of God) being the locus of manifestation of the Divine presence. Hence the Qur'ān can rightly speak a Human ruler such as the Queen of Sabā' being given (all things) as she is a typological representation on the microcosm with her arsh azim of the True 'Throne of Power' through which the $M \bar{a}$ ' (really the human Being) is the conduit for it to flow.

The subject of the ontological synonymy of Allah and the arsh was mentioned in several narrations collected in the jami' $a$ or Sabih of al-Bhukārī, highly relevant to further references to the 'arsh al-'Aұimì' in another Qur'ānic verse from the same chapter, in which a discussion on the Amira al-Sabä' is presented, Sürah al-Naml (Q.

28 Translation mine. 
27:26) "And he is the Lord of the Throne of Mighty Dominion (wa buwa rabb al-'arsh al-az̧im).

Ibn Hajar presents a discussion of these 'ahādith of Bukhārî̀ including a $M u^{\prime}$ alla $q^{30}$ narration stating "and there was Allah, and there was no other thing existing) before him), and His Throne was established upon the waters." (kāna Allah wa lam yakun shay' qablah, wa keana 'arshubu 'alà al-mā'). He observes it was a common position among many philosophers in his day to hold to the ontological synonymy of the 'arsh and God. Ibn Hajar was himself not sympathetic to that view himself, stating "that the Throne did not originate with Allah the Highest, this is a fallacious opinion, and it was from the suppositions of the people of Falasafib". "The assertion in the narration that there was no other existing thing but God (while simultaneously affirming the existence of both 'throne' and 'waters') is strongly indicative of the hadith affirming the position that both the throne and the waters were latent potentialities of God, existing in His attributes and being as attributable concomitants not ontologically distinct from the deity.

However, adopting this position in no way necessitates compromising divine unicity; rather, it is an assertion of only one Ilah's ontological reality. This assertion forms part of the Qur'annic rhetorical insistence on seeing the heavens and the earth as a function of, and consubstantial extension of the 'Throne of Power'; locus for the divine presence, and conduit of the divine manifestation. Hence within the one verse of Q. 27:26 one can see an interrelationship with ten other theologominal discursive narratological elements that intersect with vital elements of the complex profundity of the Qur'ānic cosmological argument. ${ }^{32}$

${ }^{29}$ Specifically, hadīth 7426, 7427, 7428. See, al-'Asqalānī, Fatḥ al-Bārì, Vol. 14, 344345.

30 'Suspended' or given without a complete chain. A common way for imām Bukhārī to provide a thematic introduction to a new chapter in his work.

31 Ibid., 345.

32 Heavens, Earth, Water, Throne, Nür Khalifah, and Rüh. The aforementioned content of Sūrah Ibrāhīm (Q. 14:5), with the Nür Allah and the 'ayät Allah being connected with the soteriological aspects of the Qiyamat al-Kubrä as connected with the Days of Allah are intertwined with this intra-Qur'ānic narrative on those theologies vis à vis the teleological element of the Days of God, for example in Q. 70:4 we find that "The angels and the Spirit (rüb) ascend to him in a day the measure of whereof is fifty thousand years. The poetic and metaphorical nature of this statement is self-evident and the literal the interconnectivity of, Nür, ayat, and Rūh as elements of the 


\section{Concluding Remarks}

If within this exegesis we find the echoes of the mystics, Bayezid Bastāmī, al-Hallāj, et al. it is not because these thinkers are merely proffering 'ecstatic utterances' to be explained away as the excesses of drunken ecstatic piety; nor are they non-Islamic importation from some hidden crypto-Manicheanism or other Qur'ānicly incompatible 'heresy' superimposed on Islamic frameworks. Rather, as Mohammad Rustom observes on the views articulated regarding the Prophetic pinnacle of those who have obtained the full theomorphic actualization of the Nūr-i-Muhammad in tafsìr al-Fätihah of Mullā Sadra "...only the Perfect Man...can interpret the Fātiha, since, in reading it, he offers a reading of Himself". 33

This what Ibn 'Arabī referred to when he discussed the selfactualization of the internal divinity of man "... his theomorphism is (ta'allub) is a fact since he is viceregent of God in the world"34. This concept (ta'allub), is the cultivation and manifestation of divine attributes, or quite literally the doing of God-Nature. Thereby, when reading the Qur'anic text in this light, we see that there is inherent in the Qur'ānic narrative on the Adamic creation and ensoulment a divinization by imparting the divine attributes. This divinized status is thereby realized through action, or theosis of self-actualization in the performance of what the divine does, which is what he has charged mankind collectively to do by the very nature of his ontology. The God of the Qur'àn is most certainly not a man, but humanity in the Qur'ānic is essentially divine, enjoying theomorphic ontology as selfdisclosure of the Deity.

\section{References}

Alī, Maulana Muhammad. The Holy Qur'an: Text, Translation, and Commentary. Dublin, OH: Ahmadiyya Anjuman Isha'at Islam, Lahore, inc. 2002.

Allen, Spencer. The Splintered Divine: A study of Ishtar, Baal, and Yabweh Divine Names and Divine Multiplicity in the Ancient Near East. Boston: de Gruyter, 2015.

Qurānic soteriological hope for Mankind's ultimate full divinization (though outside of the scope of this paper) warrants further serious consideration.

${ }^{33}$ Rustom, The Triumph, 119.

${ }_{34}$ Ibn 'Arabī, The Meccan Revelations, trans. William Chittick, Vol. 1 (New York: Pir Press, 2005), 30. 
Ansari, Abdul Haq. Ibn 'Arabi: the Doctrine of Wabdat al Wujūd', Islamic Studies, Vol. 38, No. 2, 1999.

'Arabī, Ibn. The Meccan Revelations, trans. William Chittick, Vol. 1. New York: Pir Press, 2005.

-----. The Ringstones of Wisdom (Fusüs al-Hikam), trans. Caner Dagli. Chicago: Kazi Publications, 2010.

'Ashā'rī (al), Abū al-Hasan 'Alī b. 'Ismāî̀l. Maqālàt al-Islämìyyinn. Beirut, LB: al-Maktabah al-Așrīyah, 1990.

'Asqaāāī (al), Ibn Hajar. Fath al-Bärì: Sharh Șahīh al-Bukbārì, Vol. 9. Beirut, LB: Dār al-Kutub al-'Ilmìyah, 2009.

Bāyhaqī (al), Allah's Names and Attributes, trans. Gibril Haddad. Fenton, MI: As-Sunnah Foundation of America 1999.

Chittick, William C. The Self-Disclosure of God. New York, NY: SUNY Press, 1998.

Darwīsh, Muhy al-Dīn. I'rāb al-Qur'àn al-Karim, Vol. 1. Damascus: Dār al-Yamāmah, 2014.

Dögen, Ali Fakri. "An Outline of Qunawi's Reflections of Divine Names in The of Oneness of the Being/Wabdat al-Wujud", Mütefekekir, Vol. 1, No. 1, Spring 2014.

Fodor, Alexander. "A Group of Iraqi Arm Amulets: Popular Islam in Mesopotamia", Quaderni di Studi Arabi, Vol. 5/6, 1988.

Ghazālī (al), Abū Hāmid. The Niche of Lights, A Parallel English-Arabic Text. Provo, Utah: Brigham Young University Press, 1998.

Hịilī (al), Allāmah Jamāl al-Dīn. Sharh al-Bāb al-Hādì 'Ashar. Anwar alHoda Publications, Qom: IR: 2012.

Lane, Edward William (ed.). An Arabic-English Lexicon: Derived from the Best and the Most Copious Eastern Sources, Vol. 5. n.d.: Nabu Press, 2009.

Māturīdī (al), Abū Manșūr. Tãunilāt Abl al-Sunnah, Vol. 1. Beirut: Dār al-Kutub al-'Ilmìyah, 2005.

Mir, Mustansir. "Some Figures of Speech in the Qur'ān", Religion and Literature, Vol. 40, No. 3, 2008.

Rustom, Mohammed. The Triumph of Divine Mercy: Philosophy and Scripture in Mulla Sadra. Albany: SUNY Press, 2012.

Sadrā, Mulla. The Elixir of the Gnostics, trans. William Chittick. Provo, Utah: Brigham Young University Press/the Islamic Translation Serious, 2003.

Sahl b. Abd Allah al-Tustarī, Tafsir al-Tustari: Great Commentaries on the Holy Qur'ān, trans. Annabel Keeler. Louisville: 2011. 
Sommer, Benjamin D. The Bodies of God and the World of Ancient Israel. New York: Cambridge University Press, 2009.

Ṭabarī (al), Ibn Jarīr. Tafsìr al-Ṭabarì, Vol. 1. Beirut: Dār al-Kutub al'Ilmiyah, 2014.

Takács, Axel. "Becoming the Word: Theosis in the Eucharist and the Qur'ān” Journal of Ecumenical Studies, Vol. 46, No. 1, 2011.

Taymìyah, Ibn. al-'Aqidah al-Wasatīyah. Riyadh, SA: Darussalam, 2009.

Véronèse, Julien. "God's Names and Their Uses in the Books of Magic Attributed to King Solomon" Magic, Ritual, and Witchcraft, Vol. 5, No. 1, Summer 2010. 